\title{
PENGARUH KECERDASAN EMOSIONAL DAN STRES KERJA TERHADAP KEPUASAN KERJA DAN DAMPAKNYA TERHADAP KOMITMEN ORGANISASI FRONTLINER BAKTI PT BANK CENTRAL ASIA Tbk KCU JAMBI \\ Emma Rachmelya ${ }^{1}$, Arna Suryani ${ }^{2}$
}

\begin{abstract}
The research aims to analyze the influence of emotional intelligence, job stress and job satisfaction on organizational commitment, both directly and indirectly. This research is done on Bakti Frontliner who work as teller and customer services of PT Bank Central Asia Tbk Jambi Branch, amounted at 60 people spread in nine sub branch. Technique used in sampling is census, where all of the population is used as sample. Analysis unit used is path analysis. The research result that emotional intelligence and job satisfaction influence positively and significantly on organizational commitment, while job stress influence negatively and significantly on job satisfaction and organizational commitment. Other than that emotional intelligence and job stress influence directly on organizational commitment through job satisfaction.

Keywords: emotional intelligence, job stress, job satisfaction, organizational commitment
\end{abstract}

\section{PENDAHULUAN}

Persaingan dan tuntutan profesionalisme yang semakin tinggi menimbulkan banyaknya tekanan-tekanan yang harus dihadapi individu dalam lingkungan kerja. Tekanan yang berasal dari lingkungan kerja, lingkungan keluarga dan lingkungan sosial berpeluang menimbulkan kecemasan. Hampir setiap hari karyawan bank khususnya bagian frontliner harus menghadapi nasabah yang marah, mengajukan keluhan dan menyalahkan bank.

Stres kerja karyawan tersebut, jika tidak segera diatasi dapat berdampak pada perilaku yang tidak diharapkan oleh pihak organisasi, seperti kepuasan kerja yang rendah serta turunnya komitmen organisasional para karyawan. Kepuasan kerja akan tercapai bila kebutuhan karyawan terpenuhi melalui pekerjaan. Dimana kepuasan kerja merupakan keadaan emosi yang senang atau emosi positif yang berasal dari penilaian pekerjaan atau pengalaman seseorang. Dengan kepuasan kerja yang tinggi akan meningkatkan komitmen organisasional karyawan terhadap organisasi tempat mereka bekerja.

Komitmen organisasional merupakan identifikasi dan keterlibatan seseorang yang relatif kuat terhadap organisasi. Pengertian komitmen saat ini, memang tak lagi sekedar berbentuk kesediaan karyawan menetap pada organisasi itu dalam jangka waktu lama. Namun lebih penting dari itu, mereka mau memberikan yang terbaik kepada organisasi, bahkan bersedia mengerjakan sesuatu melampaui batas yang diwajibkan organisasi. Ini tentu saja, hanya bisa terjadi jika karyawan merasa senang dan terpuaskan pada organisasi yang bersangkutan.

\footnotetext{
${ }^{1}$ Mahasiswa Magister Manajemen FE Universitas Batanghari

${ }^{2}$ Dosen FE Universitas Batanghari
}

Pengaruh Kecerdasan Emosional dan Stres Kerja terhadap Kepuasan Kerja dan Dampaknya terhadap Komitmen Organisasi Frontliner Bakti PT Bank Central Asia Tbk KCU Jambi 
Komitmen organisasi juga dapat diartikan suatu keadaan dimana seorang karyawan memihak pada suatu organisasi tertentu dan tujuan-tujuannya dan keinginannya untuk mempertahankan keanggotaan dalam organisasi. Karyawan dengan komitmen afektif yang kuat, cenderung bertahan pada pekerjaannya karena keinginannya sendiri, sementara karyawan dengan komitmen berkelanjutan yang tinggi, akan bertahan pada pekerjaannya atas dasar kebutuhan. Adapun karyawan dengan komitmen normatif yang kuat bertahan pada pekerjaannya karena merasakan adanya keharusan atau kewajiban. Ketiga komponen komitmen ini hadir dalam diri setiap karyawan, namun dengan kadar yang berbeda-beda sehingga akan menghasilkan perilaku yang berbeda pula sebagai latar belakang dalam mempertahankan pekerjaannya.

Selain stres kerja, kecerdasan emosional merupakan faktor lainnya yang dapat mempengaruhi komitmen organisasi. Kecerdasan emosional dapat mempengaruhi perkembangan karir individu dan keberhasilan pengembangan karir karyawan diantaranya ditentukan oleh komitmen organisasi. Komitmen organisasi juga memiliki aspek yang dipengaruhi oleh emosi. Dalam dunia kerja, orang-orang yang mempunyai kecerdasan emosional yang tinggi sangat diperlukan terlebih dalam tim untuk mencapai tujuan tertentudan untuk memberikan pelayanan kepada nasabah. Kecerdasan emosional ini sangat dibutuhkan oleh karyawan bank.

Melalui kecerdasan emosional ini seorang karyawan bank belajar mengelola perasaannya sehingga dapat mengekspresikannya secara tepat dan efektif. Karyawan bank dalam pekerjaannya sehari-hari hampir selalu melibatkan perasaan dan emosi, sehingga karyawan bank dituntut untuk memiliki kecerdasan emosi yang tinggi.

Secara khusus karyawan bank membutuhkan kecerdasan emosi yang tinggi karena mereka mewakili organisasi untuk berinteraksi dengan banyak orang baik di dalam maupun di luar organisasi. Karyawan bank yang memiliki empati akan dapat memahami kebutuhan nasabah dan dapat memberikan solusi yang konstruktif.

Seorang karyawan bank yang tidak mempunyai kecerdasan emosi yang tinggi dapat ditandai dengan hal-hal berikut: mempunyai emosi yang tinggi, cepat bertindak berdasarkan emosinya, dan tidak sensitif terhadap perasaan orang lain. Orang yang tidak mempunyai kecerdasan emosi tinggi biasanya mempunyai kecenderungan menyakiti dan memusuhi orang lain.

Karyawan yang relatif puas dengan pekerjaannya akan lebih berkomitmen pada organisasi dibandingkan dengan karyawan yang memiliki komitmen organisasional yang rendah. Kecerdasan emosional dapat mempengaruhi kepuasan kerja karena berhubungan dengan kesadaran emosi yang secara positif dapat mempengaruhi hubungan sosial di tempat kerja dan diantara rekan kerja.

Obyek penelitian ini adalah karyawan frontliner Bakti BCA pada PT. Bank Central Asia Tbk Cabang Jambi (BCA). BCA dipilih sebagai lokasi penelitian karena merupakan salah satu bank swasta terbesar nasional. Bakti BCA adalah Program Corporate Social Responsibility BCA bagi para Lulusan SMA, Diploma dan Sarjana untuk mempersiapkan diri menjadi tenaga profesional di dunia kerja. Melalui proses pendidikan dan permagangan selama 1 (satu) tahun dan dapat diperpanjang sampai 3 (tiga) tahun tanpa ikatan dinas, akan membekali peserta dengan pengalaman magang 
di bidang operasional perbankan dan ilmu lainnya yang menunjang menjadi seorang profesional.

Berdasarkan uraian di atas maka penelitian ini ingin mengkaji lebih jauh tentang Pengaruh Kecerdasan Emosional dan Stres Kerja Terhadap Kepuasan Kerja dan Dampaknya Terhadap Komitmen Organisasi Frontliner Bakti PT. Bank Central Asia Tbk Cabang Jambi.

Tujuan penulis dari penelitian ini adalah : 1) Untuk mengetahui gambaran Kecerdasan Emosional, Stres Kerja, Kepuasan Kerja dan Komitmen Organisasi frontliner Bakti pada PT. Bank Central Asia Tbk Cabang Jambi. 2) Untuk mengetahui pengaruh langsung dan tidak langsung Kecerdasan Emosional, terhadap Kepuasan Kerja frontliner Bakti pada PT. Bank Central Asia Tbk Cabang Jambi. 3) Untuk mengetahui pengaruh langsung dan tidak langsung Stres Kerja, terhadap Kepuasan Kerja karyawan frontliner Bakti pada PT. Bank Central Asia Tbk Cabang Jambi. 4) Untuk mengetahui pengaruh langsung dan tidak langsung Kecerdasan Emosional dan Stres Kerja secara bersama sama terhadap Kepuasan Kerja frontliner Bakti pada PT. Bank Central Asia Tbk Cabang Jambi. 5) Untuk mengetahui pengaruh langsung dan tidak langsung Kecerdasan Emosional, terhadap Komitmen Organisasi frontliner Bakti pada PT. Bank Central Asia Tbk Cabang Jambi. 6) Untuk mengetahui pengaruh langsung dan tidak langsung Stres Kerja terhadap Komitmen Organisasi frontliner Bakti pada PT. Bank Central Asia Tbk Cabang Jambi. 7) Untuk mengetahui pengaruh langsung dan tidak langsung Kecerdasan Emosional dan Stres Kerja secara bersama sama terhadap Komitmen Organisasi frontliner Bakti pada PT. Bank Central Asia Tbk Cabang Jambi. 8) Untuk mengetahui pengaruh Kepuasan Kerja terhadap Komitmen Organisasi frontliner Bakti pada PT. Bank Central Asia Tbk Cabang Jambi. 9) Untuk mengetahui pengaruh Kecerdasan Emosional dan Stres Kerja secara bersama sama terhadap Komitmen Organisasi melalui Kepuasan Kerja.

Dengan tercapainya tujuan penelitian maka manfaat yang diharapkan oleh peneliti adalah sebagai berikut : 1) Secara akademis, penelitian ini diharapkan dapat menambah pengetahuan dan pengembangan ilmu pengetahuan khususnya bidang manajemen sumber daya manusia. Penelitian ini juga merupakan hasil penerapan antara teori perkuliahan dan kenyataan yang ada di lapangan serta diharapkan dapat digunakan sebagai bahan pengembangan ilmu. 2) Secara praktis, penelitian ini diharapkan dapat bermanfaat sebagai bahan masukan dan dasar pemikiran yang objektif serta sebagai bahan pertimbangan pengelolaan sumber daya manusia khususnya bagi manajemen PT. Bank Central Asia Tbk tentang pentingnya kecerdasan emosional, stres kerja serta kepuasan kerja untuk meningkatkan komitmen organisasional Frontliner Bakti.

\section{Landasan Teori}

\section{TINJAUAN PUSTAKA}

\section{Kecerdasan Emosional}

Seiring dengan perkembangan ilmu pengetahuan, diduga bahwa kesuksesan seseorang tidak hanya bergantung pada kecerdasan intelektual saja namun kecerdasan emosional serta peran intrapersonal seseorang turut mempengaruhinya. Kecerdasan 
emosi dewasa ini dipandang sebagai hal yang mendasar untuk bertahan di lingkungan kerja dan merupakan kemampuan utama dalam kepemimpinan dan manajerial.

Kecerdasan emosional merupakan suatu kecerdasan yang merujuk kepada kemampuan mengenali perasaan diri sendiri dan perasaan orang lain, kemampuan memotivasi diri sendiri dan kemampuan mengelola emosi dengan baik pada diri sendiri dan dalam hubungannya dengan orang lain.

Kecerdasan emosional terdiri dari 5 faktor yaitu faktor self awareness, self regulation, self motivation, empathy, dan social skill.

Self awareness

Mengenali diri merupakan inti dari kecerdasan emosional, yaitu kesadaran akan perasaan diri sendiri sewaktu perasaan timbul. Orang yang mengenali emosi dirinya akan peka terhadap suasana hati, ia akan memiliki kejernihan pikiran sehingga seseorang itu akan mandiri dan yakin atas batas-batas yang mereka bangun, kesehatan jiwanya bagus dan cenderung berpikir positif tentang kehidupan. Kemudian apabila suasana hati sedang buruk, mereka tidak mau dan tidak larut ke dalam perasaan dan mampu melepaskan dari suasanatidak nyaman dalam waktu relatif cepat.

\section{Self regulation}

Menjaga agar emosi yang muncul dapat terkendali merupakan kunci menuju kesejahteraan emosi. Emosi yang berlebihan yang meningkat dengan intensitas terlampau tinggi atau untuk waktu yang lama akan berakibat negatif terhadap kestabilan emosional seseorang. Seseorang yang memiliki kecerdasan emosional tidak akan larut dalam perasaan. Ketika kebahagiaan datang tidak diungkapkan dengan berlebihan, dan ketika merasa menderita tidak membiarkan perasaan negatif langsung tidak terkendali.

\section{Self motivation}

Motivasi merupakan dorongan dari dalam yang menimbulkan kekuatan individu untuk bertindak atau bertingkah laku guna memenuhi kebutuhannya. Motivasi yang merupakan bagian dari emosi erat hubungannya dengan keberhasilan, bisa membuat kita merasakan kepuasan sejati yang bahkan lebih besar daripada keberhasilan itu sendiri. Motivasi memiliki kekuatan yang luar biasa dalam kehidupan seseorang.

\section{Empathy}

Kemampuan mengenali emosi orang lain (empati) adalah merasakan yang dirasakan orang lain, mampu memahami perspektif mereka, menumbuhkan hubungan saling percaya dan menyelaraskan diri dengan bermacam-macam orang. Empati ialah bereaksi terhadap perasaan orang lain dengan respon emosional yang sama dengan orang tersebut. Empati menekankan pentingnya mengindra perasaan dan perspektif orang lain sebagai dasar untuk membangun hubungan interpersonal yang sehat.

\section{Social skills}

Membina hubungan merupakan ketrampilan yang menunjang popularitas, kepemimpinan, dan keberhasilan antar pribadi Dalam rangka membangun hubungan sosial yang harmonis terdapat dua hal yang harus diperhatikan terlebih dahulu, yaitu: citra diri dan kemampuan berkomunikasi. Citra diri sebagai kapasitas diri yang benarbenar siap untuk membangun hubungan sosial. Citra diri dimulai dari dalam diri 
masing-masing, kemudian melangkah keluar sebagaimana ia mempersepsikan orang lain. Sedangkan kemampuan komunikasi merupakan kemampuan dalam mengungkapkan kalimat-kalimat yang tepat.

\section{Stres Kerja}

Stres kerja adalah suatu kondisi ketegangan yang menciptakan adanya ketidakseimbangan fisik dan psikis, yang mempengaruhi emosi, proses berfikir, dan kondisi seorang karyawan. Stres dapat bersifat positif maupun negatif. Stres yang bersifat positif disebut -eustres, yakni mendorong manusia untuk lebih dapat berprestasi, lebih tertantang untuk menyelesaikan masalah-masalah yang dihadapinya, sebaiknya stres yang berlebihan dan bersifat merugikan atau negatif -distres, menimbulkan berbagai macam gejala yang umumnya merugikan kinerja karyawan.

Ada enam dimensi stres kerja yaitu:

1. Perilaku pribadi yaitu keadaan atau aktifitas dari karyawan itu sendiri didalam organisasi.

2. Dukungan sosial yaitu dukungan dari dalam organisasi maupun dukungan dari luar organisasi.

3. Konflik peran yaitu kondisi dimana karyawan memikul tugas atau jabatan dan menanggung semua konsekuensinya yang berhubungan dengan pekerjaan dalam perusahaan.

4. Lingkungan buruk yaitu keadaan disekitar organisasi terutama di dalam ruang kerja.

5. Beban kerja yaitu keadaan pekerjaan yang dibebankan kepada karyawan atau jenis pekerjaan yang harus diselesaikan tepat waktu.

6. Situasi rumah dan pekerjaan yaitu kondisi antara keadaan di rumah tangga dengan keadaan yang ada di perusahaan.

\section{Kepuasan Kerja}

Kepuasan kerja merupakan evaluasi yang menggambarkan seseorang atas perasaan sikapnya senang atau tidak senang, puas atau tidak puas dalam bekerja. ${ }^{[8]}$ Apabila pegawai bergabung dalam suatu instansi mereka akan membawa seperangkat keinginan, kebutuhan, hasrat dan pengalaman masa lalu yang menyatu membentuk harapan kerja, Kepuasan Kerja menunjukan kesesuaian antara harapan seseorang yang timbul dan imbalan yang disediakan pekerjaan.

Terdapat lima dimensi yang mempengaruhi kepuasan kerja, yaitu:

1. Pembayaran.

Karyawan menginginkan sistem gaji, upah dan jaminan kesehatan yang dipersepsikan sebagai adil, tidak meragukan dan segaris dengan pengharapannya. Bila upah dilihat sebagai adil yang didasarkan pada tuntutan pekerjaan, tingkat ketrampilan individu, dan standar pengupahan komunitas kemungkinan besar akan dihasilkan kepuasan;

2. Pekerjaan itu sendiri.

Karyawan cenderung lebih menyukai pekerjaan-pekerjaan yang memberi kesempatan untuk mengunakan kemampuan dan ketrampilannya, kebebasan, dan umpan balik mengenai betapa baik mereka bekerja. Karakteristik ini membuat kerja lebih menantang. Pekerjaan yang kurang menantang menciptakan kebosanan,

Pengaruh Kecerdasan Emosional dan Stres Kerja terhadap Kepuasan Kerja dan Dampaknya terhadap Komitmen Organisasi Frontliner Bakti PT Bank Central Asia Tbk KCU Jambi 
tetapi yang terlalu banyak menantang juga dapat menciptakan frustasi dan perasaan gagal;

3. Rekan kerja.

Bagi kebanyakan karyawan kerja juga mengisi kebutuhan akan interaksi sosial. Oleh karena itu tidaklah mengejutkan bila mempunyai rekan kerja yang ramah dan mendukung menghantar ke kepuasan kerja yang meningkat;

4. Promosi pekerjaan.

Promosi terjadi pada saat seorang karyawan berpindah dari suatu pekerjaan ke posisi lainnya yang lebih tinggi, dengan tanggung jawab dan jenjang organisasionalnya. Pada saat dipromosikan karyawan umumnya menghadapi peningkatan tuntutan dan keahlian, kemampuan dan tanggung jawab. Sebagian besar karyawan merasa positif karena dipromosikan. Promosi memungkinkan organisasi untuk mendayagunakan kemampuan dan keahlian karyawan setinggi mungkin;

5. Kepenyeliaan (supervisi).

Supervisi mempunyai peran yang penting dalam manajemen. Supervisi berhubungan dengan karyawan secara langsung dan mempengaruhi karyawan dalam melakukan pekerjaannya. Umumnya karyawan lebih suka mempunyai supervisi yang adil, terbuka dan mau bekerjasama dengan bawahan.

6. Komitmen Organisasi

Komitmen organisasi adalah keinginan kuat untuk tetap bertahan sebagai anggota organisasi, keinginan untuk berusaha sesuai keinginan organisasi, keyakinan tertentu dan penerimaan nilai dan tujuan organisasi. ${ }^{[10]}$ Komitmen organisasional sebagai sebuah keadaan psikologi yang mengkarakteristikkan hubungan karyawan dengan organisasi atau implikasinya yang mempengaruhi apakah karyawan akan tetap bertahan dalam organisasi atau tidak, yang teridentifikasi dalam tiga komponen yaitu:

Komitmen afektif (affective commitment), yaitu: perasaaan cinta pada suatu organisasi yang memunculkan kemauan untuk tetap tinggal dan membina hubungan sosial serta menghargai nilai hubungan dengan organisasi dikarenakan telah menjadi anggota organisasi.

Komitmen kelanjutan (continuance commitment), yaitu: persepsi seseorang atas biaya dan resiko dengan meninggalkan organisasi saat ini. Artinya, terdapat dua aspek pada komitmen kelanjutan, yaitu: melibatkan pengorbanan pribadi apabila meninggalkan organisasi dan ketiadaan alternatif yang tersedia bagi orang tersebut.

Komitmen normatif (normative commitment), yaitu: perasaan yang mengharuskan untuk bertahan dalam organisasi dikarenakan kewajiban dan tanggung jawab terhadap organisasi yang didasari atas pertimbangan norma, nilai dan keyakinan karyawan.

Secara umum, karyawan yang memiliki komitmen afektif yang kuat akan tetap tinggal bersama organisasi dikarenakan mereka ingin tinggal (because they want to). Para karyawan yang memiliki komitmen kontinyu yang kuat dikarenakan mereka harus tinggal bersama organisasi (because they have to). Dan para 
karyawan yang memiliki komitmen normatif yang kuat dikarenakan mereka merasa bahwa mereka harus tinggal bersama (because they fell that they have to).

\section{Hubungan antar variabel penelitian}

\section{Hubungan antar Kecerdasan Emosional terhadap Kepuasan Kerja}

Kecerdasan emosional merupakan komponen yang membuat seseorang menjadi pintar dalam menggunakan emosinya. Dalam bekerja kecerdasan emosional sangat berhubungan dengan kepuasan kerja, dimana kepuasan kerja merupakan sikap emosional yang menyenangkan dan mencintai pekerjaannya. Kecerdasan emosional yang terganggu akan menyebabkan seseorang tidak dapat mencapai kepuasan kerja yang maksimal. Adanya hubungan antara kecerdasan emosional dan kepuasan kerja frontliner Bakti BCA berarti bahwa dengan pengenalan dan pengelolaan emosi yang baik dari frontliner Bakti BCA dapat menghasilkan emosi yang positif dalam bekerja serta mampu menempatkan emosi tersebut pada waktu yang tepat, sehingga dengan emosi positif tersebut dapat menghasilkan rasa kepuasan dalam bekerja.

Demikian pula seorang frontliner Bakti BCA, ketika ia mampu mengenali emosi rekan kerja dan nasabahnya dengan baik serta mampu bekerja sama dengan baik, maka hal tersebut dapat memberikan rasa kepuasan tersendiri dalam bekerja, dibandingkan bila mereka tidak dapat mengenali emosi rekan kerja serta nasabah dengan baik maka akan menyebabkan kesalahpahaman dan kesulitan dalam bekerja, serta menyebabkan tidak maksimal dalam memberikan pelayanan pada nasabah. Demikian juga halnya dalam memberikan rasa kepuasan dalam bekerja, seorang frontliner Bakti BCA perlu mengemukakan apa yang dirasakan dari dalam dirinya terhadap pekerjaan yang dikerjakan, bagaimana mereka menyatakan pendapat tentang pekerjaan, mengungkapkan perasaan mereka, keyakinan pada apa yang dikerjakan. Kepercayaan dan penghargaan terhadap diri sendiri atau pada kemampuannya dalam bekerja, juga menjadi alasan mereka dapat memiliki rasa kepuasan. Selain itu ketika frontliner Bakti BCA menghadapi tantangan atau berada pada kondisi yang tidak menyenangkan, mereka mampu untuk menghadapinya serta memiliki kepercayaan diri untuk tetap terus maju, yang pada akhirnya mampu kembali menunjukkan potensi diri yang baik dalam bekerja dan memiliki komitmen yang tinggi.

\section{Hubungan antar Stres Kerja terhadap Kepuasan Kerja}

Stres yang berhubungan dengan pekerjaan secara konseptual sebagai wujud ketidakseimbangan yang dirasakan individu dengan individu-individu lain pada lingkungan pekerjaan. Kondisi kehidupan yang tidak menyenangkan menyebabkan ketidaknyamanandalam bekerja, sehingga hal ini dapat menimbulkan stres dalam bekerja yang akhirnya dapat menurunkan kepuasan kerja.

Stres merupakan respon adaptif terhadap situasi eksternal yang menghasilkan penyimpangan fisik, psikologis dan atau perilaku pada anggota organisasi. Dampak stres sangat beragam, misalnya dampak subyektif seperti kecemasan, agresi, bersikap acuh, kebosanan, depresi, keletihan, kehilangan kesabaran, rendah diri, gugup dan lain sebagainya. Dampak perilaku (Behaviour effect) terhadap stres antara lain emosi yang tiba-tiba meledak, perilaku yang mengikuti kata hati, makan yang berlebihan dan alkoholik. Dampak kognitif yang diakibatkan antara lain konsentrasi yang buruk dan sangat peka terhadap kritik, sedangkan dampak psikologis yang ditimbulkan seperti meningkatnya kadar gula, meningkatnya denyut jantung dan tekanan darah,

Pengaruh Kecerdasan Emosional dan Stres Kerja terhadap Kepuasan Kerja dan Dampaknya terhadap Komitmen Organisasi Frontliner Bakti PT Bank Central Asia Tbk KCU Jambi 
kekeringan pada mulut, membesarnya pupil mata dan tubuh panas dingin. Dampak stres pada organisasi antara lain keabsenan, rendahnya produktifitas, rendahnya kepuasan kerja dan rendahnya komitmen terhadap organisasi.

\section{Hubungan antar Kecerdasan Emosional terhadap Komitmen Organisasi}

Individu dengan kecerdasan emosional yang tinggi, lebih berkomitmen pada organisasi mereka. Kecerdasan emosional memiliki hubungan yang berarti dengan hasil pekerjaan seperti kepuasan kerja dan komitmen organisasional. Artinya, karyawan yang tidak dapat mengatur emosi mereka dengan baik, menunjukkan kurang memiliki komitmen organisasional. Selain itu individu yang memiliki kecerdasan emosional yang tinggi cenderung memiliki komitmen organisasional yang tinggi pula.

\section{Hubungan antar Stres Kerja terhadap Komitmen Organisasi}

Seorang Frontliner Bakti BCA yang mengalami stres akan berpengaruh terhadap menurunnya rasa senang (antusiasme) pada pekerjaan, perhatian pada organisasi dan rekan sekerja, bahkan mungkin sampai pada hilangnya rasa tanggung jawab dalam melayani nasabah. Dampak stres akan berpengaruh terhadap tingkat komitmen organisasional mereka. Stres kerja yang rendah cenderung diikuti dengan peningkatan komitmen organisasi sehingga semakin tinggi pula komitmen Frontliner Bakti BCA terhadap BCA sebagai tempat mereka bekerja.

\section{Hubungan antar Kepuasan Kerja terhadap Komitmen Organisasi}

Meskipun kepuasan berkaitan dengan sikap karyawan terhadap pekerjaan dan komitmen organisasional berkaitan dengan level organisasi, tetapi hubungan yang kuat antara kepuasan kerja dan komitmen organisasional telah diketahui sejak lama. Kepuasan kerja yang dibentuk dalam penelitian ini terdiri dari komponen kepuasan akan pekerjaan, rekan kerja, pengawasan, upah dan promosi secara positif berhubungan dengan komitmen organisasional. Jika kepuasan frontliner Bakti BCA terpenuhi dan semakin meningkat, maka frontliner Bakti BCA akan semakin memiliki komitmen yang tinggi terhadap BCA sebagai tempat mereka bekerja dan merasa bangga menjadi bagian dari BCA.

\section{Kerangka Pemikiran}

Kerangka pemikiran merupakan kerangka berpikirnya peneliti terhadap apa yang menjadi objek penelitian. Kerangka pemikiran berusaha menjelaskan konstelasi hubungan antar variabel yang akan diteliti.

Kerangka pemikiran yang diajukan pada penelitian ini meliputi variabel kecerdasan emosional, stress kerja, kepuasan kerja dan komitmen organisasi. Variabel yang dianalisa adalah variabel independen yaitu Kecerdasan Emosional (X1) dan Stres Kerja (X2), sedangkan variabel dependen adalah Kepuasan Kerja (Y) dan Komitmen Organisasi (Z). Dimana masing-masing variabel bebas memiliki indikator yang mempengaruhi disebut variabel intervening. Variabel bebas dan variabel intervening juga berpengaruh terhadap variabel terikat.

\section{Hipotesis Penelitian}

Atas dasar landasan teori dan kerangka pemikiran di atas, maka penulis menggunakan hipotesis penelitian sebagai berikut: 
1. Kecerdasan Emosional, Stres Kerja, Kepuasan Kerja dan Komitmen karyawan frontliner BCA Jambi dinilai tinggi.

2. Kecerdasan Emosional diduga berpengaruh signifikan terhadap Kepuasan Kerja

3. Stres Kerja diduga berpengaruh signifikan terhadap Kepuasan Kerja

4. Kecerdasan Emosional dan Stres Kerja secara bersama-sama diduga berpengaruh signifikan terhadap Kepuasan Kerja

5. Kecerdasan Emosional diduga berpengaruh signifikan terhadap Komitmen Organisasi

6. Stres Kerja diduga berpengaruh signifikan terhadap Komitmen Organisasi

7. Kecerdasan Emosional dan Stres Kerja secara bersama-sama diduga berpengaruh signifikan terhadap Komitmen Organisasi

8. Kepuasan Kerja diduga berpengaruh signifikan terhadap Komitmen Organisasi

\section{Objek Penelitian dan Populasi Data}

\section{METODOLOGI PENELITIAN}

Obyek penelitian adalah karyawan frontliner Bakti PT. Bank Central Asia Tbk Cabang Jambi pada tahun 2016 yang berjumlah 60 orang yang tersebar di seluruh Kantor Cabang Utama, Kantor Cabang Pembantu dan Kantor Kas. Teknik yang digunakan dalam pengambilan sampel adalah sensus, dimana seluruh populasi digunakan sebagai sampel.

\section{Metode Penelitian}

Dalam penelitian ini penulis menggunakan metode deskriptif verifikatif dengan tujuan menjelaskan, meringkaskan berbagai kondisi, berbagai situasi, atau berbagai variabel yang timbul di masyarakat yang menjadi objek penelitian itu berdasarkan apa yang terjadi. Kemudian mengangkat ke permukaan karakter atau gembaran tentang kondisi, situasi ataupun variabel tersebut.

\section{Jenis dan Sumber Data}

Jenis data dalam penelitian ini ada dua macam, yaitu jenis data primer dan jenis data sekunder.

1. Data primer yaitu data yang dibuat oleh peneliti untuk maksud khusus menyelesaikan permasalahan yang sedang ditanganinya. Data dikumpulkan sendiri oleh peneliti langsung dari sumber pertama atau tempat objek penelitian dilakukan.

2. Data sekunder yaitu data yang telah dikumpulkan untuk maksud selain menyelesaikan masalah yang sedang dihadapi. Data ini dapat ditemukan dengan cepat. Dalam penelitian ini yang menjadi sumber data sekunder adalah literatur, artikel, jurnal serta situs di internet yang berkenaan dengan penelitian yang dilakukan.

\section{Teknik Pengumpulan Data}

\section{Penelitian lapangan (field Research)}

Untuk mendapatkan data primer dilakukan dengan cara penyebaran kuesioner dan wawancara.

\section{Penelitian Kepustakaan (Library Research)}

Dalam penelitian ini penulis mengumpulkan data dengan cara membaca, mempelajari dan menelaah literatur-literatur yang relevan dengan topik yang dibahas. 
Penelitian kepustakaan dimaksudkan untuk memperoleh data sekunder dalam menunjang data primer yang telah didapat dari penelitian lapangan.

\section{Melalui Internet}

Melalui internet dapat memperluas pengetahuan dan mengetahui perkembangan terbaru mengenai masalah yang sedang diteliti.

\section{Operasional Variabel}

Kecerdasan emosional merupakan suatu kecerdasan yang merujuk kepada kemampuan mengenali perasaan diri sendiri dan perasaan orang lain, kemampuan memotivasi diri sendiri dan kemampuan mengelola emosi dengan baik pada diri sendiri dan dalam hubungannya dengan orang lain. Dimensi untuk mengukur kecerdasan emosional meliputi: kesadaran diri, pengaturan diri, motivasi diri sendiri, empati dan keterampilan sosial.

Stres kerja adalah suatu kondisi ketegangan yang menciptakan adanya ketidakseimbangan fisik dan psikis, yang mempengaruhi emosi, proses berfikir, dan kondisi seorang karyawan. Dimensi untuk mengukur stres kerja meliputi: perilaku pribadi, dukungan sosial, konflik peran, lingkungan buruk, beban kerja, situasi rumah dan pekerjaan.

Kepuasan kerja merupakan evaluasi yang menggambarkan seseorang atas perasaan sikapnya senang atau tidak senang, puas atau tidak puas dalam bekerja. ${ }^{[8]}$ Dimensi untuk mengukur kepuasan kerja meliputi: pembayaran, pekerjaan itu sendiri, rekan kerja, promosi dan supervisi.

Komitmen organisasi adalah keinginan kuat untuk tetap bertahan sebagai anggota organisasi, keinginan untuk berusaha sesuai keinginan organisasi, keyakinan tertentu dan penerimaan nilai dan tujuan organisasi. Dimensi untuk mengukur komitmen organisasi meliputi: komitmen afektif, komitmen kelanjutan dan komitmen normatif.

\section{Metode Analisis}

\section{Analisa Deskriptif}

Untuk menjawab tujuan pertama dan hipotesis pertama digunakan analisis deskriptif dengan alat analisis rentang skala Likert (Likert Scale). Analisis deskriptif mempunyai fungsi untuk memberikan gambaran umum tentang data yang telah diperoleh. Dasar penafsiran yang digunakan dalam penelitian ini mengacu dari skor penafsiran pada yaitu mulai dari: Sangat Tidak Setuju/Sangat Kurang, Tidak Setuju/Kurang, Ragu/Sedang, Setuju/Tinggi dan Sangat Setuju/Sangat Tinggi.

\section{Analisa Inferensial}

Untuk menjawab tujuan penelitian kedua hingga ke sembilan digunakan metode analisis jalur (path analysis) yang merupakan suatu metode pendekomposisian korelasi ke dalam bagian-bagian yang berbeda untuk menginterprestasikan suatu pengaruh/efek. Metode path analysis ini juga digunakan untuk menelaah hubungan antara model kausal yang dirumuskan atas dasar pertimbangan teoritis dan pengetahuan tertentu.

\section{Koefisien Determinasi}

Koefisien determinasi adalah salah satu nilai statistik yang dapat digunakan untuk mengetahui apakah data hubungan pengaruh antara variabel independen dan 
variabel dependen. Nilai koefisien determinasi menunjukkan presentase variasi nilai variabel dependen yang dapat dijelaskan oleh persamaan regresi $\left(\mathrm{R}^{2}\right)$. Semakin besar koefisien determinasi menunjukkan semakin baik kemampuan $\mathrm{X}$ mempengaruhi $\mathrm{Y}$.

\section{Pengujian Hipotesis}

Uji simultan (Uji - F)

Uji simultan (uji F) digunakan untuk melihat pengaruh secara simultan antara variabel independen dengan variabel dependen. Untuk uji F, Dasar pengambilan keputusan diambil dengan membandingkan $\mathrm{F}_{\text {hitung }}$ dengan $\mathrm{F}_{\text {tabel }}$ adalah:

Jika $F_{\text {hitung }}>\mathrm{F}_{\text {tabel }}$ maka Ho ditolak dan $\mathrm{H}_{1}$ diterima

Jika $\mathrm{F}_{\text {hitung }}<\mathrm{F}_{\text {tabel }}$ maka Ho diterima dan $\mathrm{H}_{1}$ ditolak

$\mathrm{PYX} 1=\mathrm{PYX} 2=0$

Ho : PYX1 $=0=$ Tidak ada pengaruh antara variabel independent secara bersamasama terhadap variabel dependent.

$\mathrm{PYX} 1=\mathrm{PYX} 2 \neq 0$

Ho : PYX $1 \neq 0=$ Ada pengaruh antara variabel independent secara bersama-sama terhadap variabel dependent.

Rancangan uji hipotesis ini disajikan berdasarkan tujuan penelitian. Tingkat kepercayaan yang digunakan adalah 95\%, sehingga tingkat presesi atau batas ketidakakuratan sebesar $\alpha=5 \%=0.05$.

Dasar pengambilan keputusan:

Nilai probabilitas $<5 \%$ berarti $\mathrm{Ho} \rightarrow$ ditolak dan $\mathrm{H} 1 \rightarrow$ diterima, artinya koefisien signifikan.

Nilai probabilitas $>5 \%$ berarti $\mathrm{Ho} \rightarrow$ diterima dan $\mathrm{H} 1 \rightarrow$ ditolak, artinya koefisien tidak signifikan.

\section{Uji Parsial (Uji-T)}

Uji t digunakan untuk melihat pengaruh secara parsial antara variabel independent dan variabel dependent. Berdasarkan hasil dari pengujian uji t, maka akan diperoleh suatu hasil berupa thitung yang akan dibandingkan dengan $t_{\text {tabel }}$ yang digunakan sebagai dasar pengambilan keputusan pengujian:

- Jika $t_{\text {hitung }} \geq \mathrm{t}_{\text {tabel }}$ maka Ho ditolak, dan H1 diterima

- Jika $t_{\text {hitung }} \leq \mathrm{t}_{\text {tabel }}$ maka Ho diterima, dan H1 ditolak.

Dan keputusan yang akan diambil adalah:

Nilai probabilitas $<5 \%$ berarti $\mathrm{Ho} \rightarrow$ ditolak dan $\mathrm{H} 1 \rightarrow$ diterima, artinya koefisien signifikan.

Nilai probabilitas $>5 \%$ berarti $\mathrm{Ho} \rightarrow$ diterima dan $\mathrm{H} 1 \rightarrow$ ditolak, artinya koefisien tidak signifikan.

Pengaruh Kecerdasan Emosional dan Stres Kerja terhadap Kepuasan Kerja dan Dampaknya terhadap Komitmen Organisasi Frontliner Bakti PT Bank Central Asia Tbk KCU Jambi 


\section{HASIL DAN PEMBAHASAN \\ Hasil Statistik Deskriptif Variabel-Variabel Penelitian}

Sesuai hasil rentang pengklasifikasian, secara umum nilai bobot skor total pada variabel kecerdasan emosional tergolong tinggi, hal ini dapat dikatakan bahwa responden memiliki kecerdasan emosional yang baik. Sedangkan untuk variabel stres kerja, secara umum memiliki bobot skor total tinggi, yang artinya responden sedang dalam kondisi stres kerja yang tinggi. Deskripsi variabel kepuasan kerja secara umum berada pada daerah sedang dan deskripsi variabel komitmen organisasi juga berada pada daerah sedang.

\section{Hasil Analisa Jalur (Path Analysis)}

Hipotesis penelitian diuji dengan menggunakan analisis jalur. Diagram jalur akan membuktikan adanya pengaruh antara kecerdasan emosional, stres kerja, kepuasan kerja dan komitmen organisasional. Diagram berikut ini adalah ringkasan hasil analisis jalur pada model hipotesis penelitian ini

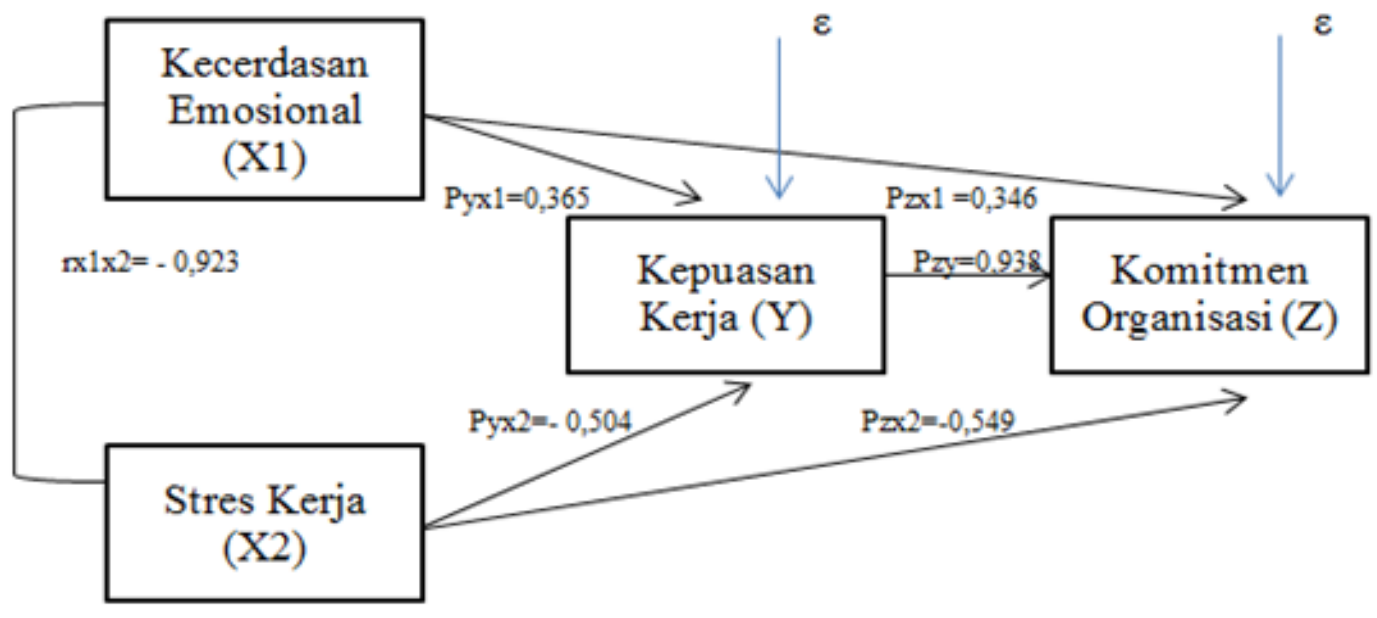

Gambar 1. Hasil Analisa Jalur

\section{Ketepatan Model}

Ketepatan model hipotesis dari data penelitian diukur dari hubungan tiga koefisien determinasi ( $\mathrm{R}$ Square) diketiga persamaan. Pada persamaan pertama diperoleh nilai sebesar 0,725 (R Square 1) persamaan kedua 0,772 (R Square 2) dan 0,880 ( $\mathrm{R}$ Square 3) pada persamaan ketiga. Hasil perhitungan tentang ketepatan model menyatakan bahwa kontibusi model untuk menjelaskan hubungan kausal dari keempat variabel yang diteliti sebesar 75,4\%. Sedangkan 24,6\% keragaman sisanya dijelaskan oleh variabel lain yang tidak terdapat di dalam model path.

\section{Analisis Deskriptif Kecerdasan Emosional, Stres Kerja, Kepuasan Kerja dan} Komitmen Organisasi

Kecerdasan Emosional mendapatkan skor total dengan kategori tinggi. Dengan demikian kecerdasan emosional pada frontliner Bakti BCA KCU Jambi dinilai Tinggi dan sesuai dengan hipotesis awal yang mengatakan Kecerdasan Emosional tinggi. Dimana skor tertinggi berada pada pernyataan dimensi kesadaran diri dimana 
frontliner Bakti BCA sudah bisa mengenal dan memahami emosi serta kelebihan dan kekurangan yang mereka miliki. Sedangkan untuk skor yang paling rendah adalah pada dimensi empati dimana frontliner Bakti BCA belum sepenuhnya yakin mereka adalah pendengar yang baik dan memberikan solusi yang tepat bagi nasabah.

Stres Kerja mendapatkan skor total dengan kategori Tinggi. Dengan demikian stres kerja pada frontliner Bakti BCA KCU Jambi dinilai Tinggi dan sesuai dengan hipotesis awal yang mengatakan stres kerja tinggi. Dimana skor tertinggi pertama berada pada pernyataan dimensi perilaku pribadi dimana frontliner Bakti BCA belum meyakini kualitas hasil pekerjaan mereka sesuai dengan harapan BCA. Hal ini penting bisa terlihat dari hasil survey BSQ dan CE serta pencapaian-pencapaian prestasi lainnya dimana pekerjaan mereka belum menunjukkan prestasi yang diharapkan. Skor tertinggi kedua berada pada pernyataan dimensi lingkungan dimana frontliner Bakti BCA merasa terbebani dengan banyaknya volume dan jumlah nasabah yang bertransaksi di banking hall. Sedangkan untuk skor yang paling rendah adalah pada dimensi beban kerja dimana frontliner Bakti BCA belum sepenuhnya yakin keterampilan dan kemampuan saya tidak digunakan dengan baik dalam menunjang pekerjaan sebagai CS dan Teller.

Kepuasan Kerja mendapatkan skor dengan kategori sedang. Dengan demikian kepuasan kerja pada frontliner Bakti BCA KCU Jambi dinilai sedang dan tidak sesuai dengan hipotesis awal yang mengatakan Kepuasan Kerja Tinggi. Skor tertinggi berada pada pernyataan dimensi pembayaran dimana frontliner Bakti BCA merasa puas dengan jaminan kesehatan yang diberikan selama program magang. Sedangkan untuk skor yang paling rendah pertama adalah pada dimensi pekerjaan dimana frontliner Bakti BCA merasa kurang puas karena waktu kerja dirasakan selalu kurang untuk menyelesaikan pekerjaan dimana berdasarkan hasil survey yang dilakukan kegiatan lembur masih sering dilakukan oleh frontliner Bakti BCA terutama pada hari Senin dan Jumat. Skor yang paling rendah kedua adalah pada dimensi promosi dimana frontliner Bakti BCA merasa kurang puas karena tidak memiliki kesempatan yang yang pasti untuk bisa meneruskan karir di BCA sebagai karyawan tetap.

Komitmen organisasi mendapatkan skor dengan kategori sedang. Dengan demikian komitmen organisasi pada frontliner Bakti BCA KCU Jambi dinilai sedang dan tidak sesuai dengan hipotesis awal yang mengatakan komitmen organisasi Tinggi. Skor tertinggi berada pada pernyataan dimensi komitmen normatif dimana Bakti BCA merasa setia dengan BCA. Sedangkan untuk skor yang paling rendah pertama adalah pada dimensi normatif dimana frontliner Bakti BCA merasa siap meninggalkan BCA kapan saja walaupun memiliki tanggung jawab dan kewajiban yang harus saya kerjakan.

\section{Analisis Inferensial Kecerdasan Emosional, Stres Kerja, Kepuasan Kerja dan Komitmen Organisasi \\ Hipotesis 2}

Kecerdasan Emosional secara langsung berpengaruh positif terhadap Kepuasan Kerja dengan pengaruh langsung Kecerdasan Emosional terhadap kepuasan kerja sebesar $13,2 \%$ pengaruh tidak langsung sebesar $17 \%$ dan pengaruh total sebanyak $30,2 \%$. Hal tersebut di lengkapi dengan hipotesis kedua menyatakan bahwa 
Kecerdasan Emosional berpengaruh positif dan signifikan terhadap Kepuasan Kerja, hal ini terbukti berdasarkan nilai $t_{\text {hitung }} 2,019>t_{\text {tabel }} 1,671$ atau karena nilai sig. 0,048 < 0,05 maka Ho ditolak dan H1 diterima artinya hipotesis diterima dan signifikan. Hasil yang didapat menunjukkan bahwa Kecerdasan Emosional Karyawan Frontliner Bakti PT. Bank Central Asia Tbk Cabang Jambi berpengaruh positif dan signifikan terhadap Kepuasan Kerja. Hal ini mendukung penelitian terkait Emdady et al (jurnal:2013) yang menyatakan Kecerdasan Emosional Karyawan berpengaruh positif dan signifikan terhadap Kepuasan Kerja.

\section{Hipotesis 3}

Stres Kerja secara langsung berpengaruh negatif terhadap Kepuasan Kerja dengan pengaruh langsung Stres Kerja terhadap kepuasan kerja sebesar 25,4\% pengaruh tidak langsung sebesar $17 \%$ dan pengaruh total sebanyak 42,3\%. Hal tersebut di lengkapi dengan Hipotesis ketiga menyatakan bahwa Stres Kerja berpengaruh positif dan signifikan terhadap Kepuasan Kerja dan berdasarkan nilai $t_{\text {hitung }}-2,788<\mathrm{t}_{\text {tabel }} 1,671$ atau karena nilai sig. 0,007 $<0,05$ maka Ho ditolak dan H1 diterima artinya hipotesis diterima dan signifikan. Hasil yang didapat menunjukkan bahwa Stres Kerja Karyawan Frontliner Bakti PT. Bank Central Asia Tbk Cabang Jambi berpengaruh negatif dan signifikan terhadap Kepuasan Kerja.

Hal ini mendukung penelitian terkait Bemana et, al (jurnal:2013) yang menyatakan Kecerdasan Emosional Karyawan berpengaruh negatif dan signifikan terhadap Kepuasan Kerja.

\section{Hipotesis 4}

Kecerdasan Emosional dan Stres Kerja secara bersama-sama memiliki total pengaruh terhadap Kepuasan Kerja sebesar $72,5 \%$ dimana angka tersebut menjelaskan bahwa secara langsung Kecerdasan Emosional dan Stres Kerja memberikan kontribusi terhadap Kepuasan Kerja sebesar 72,5\% pada frontliner Bakti BCA KCU Jambi.

Hal tersebut di lengkapi dengan Hipotesis keempat menyatakan bahwa Kecerdasan Emosional dan Stres Kerja secara bersama-sama berpengaruh signifikan terhadap Kepuasan Kerja, hal ini terbukti berdasarkan nilai $F_{\text {hitung }} 75,232>\mathrm{F}_{\text {tabel }} 0,254$ atau karena nilai sig. 0,000 $<0,05$ maka Ho ditolak dan $\mathrm{H} 1$ diterima artinya hipotesis diterima dan signifikan. Hal ini menunjukkan bahwa secara simultan Kecerdasan Emosional dan Stres Kerja berpengaruh secara signifikan terhadap Kepuasan Kerja dan mendukung penelitian terkait dari Ismail, et al (jurnal:2010). ${ }^{[13]}$

\section{Hipotesis 5}

Kecerdasan Emosional secara langsung berpengaruh positif terhadap Komitmen Organisasi dengan pengaruh langsung Kecerdasan Emosional terhadap Komitmen Organisasi sebesar $11,9 \%$ pengaruh tidak langsung sebesar 17,6\% dan pengaruh total sebanyak 29,5\%. Hal tersebut di lengkapi dengan Hipotesis kelima menyatakan bahwa Kecerdasan Emosional berpengaruh positif dan signifikan terhadap Komitmen Organisasi, hal ini terbukti berdasarkan nilai $t_{\text {hitung }} 2,099>\mathrm{t}_{\text {tabel }} 1,671$ atau karena nilai sig. 0,040 < 0,05 maka Ho ditolak dan H1 diterima artinya hipotesis diterima dan signifikan. Hasil yang didapat menunjukkan bahwa Kecerdasan Emosional Karyawan Frontliner Bakti PT. Bank Central Asia Tbk Cabang Jambi berpengaruh positif dan signifikan terhadap Komitmen Organisasi. Hal ini mendukung penelitian Ates 
(jurnal:2015) dan Aghabiozorgi et al (jurnal: 2014) yang menyatakan Kecerdasan Emosional Karyawan berpengaruh positif dan signifikan terhadap Komitmen Organisasi.

\section{Hipotesis 6}

Stres Kerja secara langsung berpengaruh negatif terhadap Komitmen Organisasi dengan pengaruh langsung Stres Kerja terhadap Komitmen Organisasi sebesar $30,1 \%$ pengaruh tidak langsung sebesar $17,6 \%$ dan pengaruh total sebanyak $47,7 \%$. Hal tersebut di lengkapi dengan Hipotesis keenam menyatakan bahwa Stres Kerja berpengaruh positif dan signifikan terhadap Komitmen Organisasi, hal ini terbukti berdasarkan nilai $t_{\text {hitung }}-3,355>\mathrm{t}_{\text {tabel }} 1,671$ dan karena nilai sig. $0,002<0,05$ maka Ho ditolak dan H1 diterima artinya hipotesis diterima dan signifikan. Hasil yang didapat menunjukkan bahwa Stres Kerja Karyawan Frontliner Bakti PT. Bank Central Asia Tbk Cabang Jambi berpengaruh negatif dan signifikan terhadap Komitmen Organisasi.

Hal ini mendukung penelitian dari Karambut (jurnal:2012) yang menyatakan Stres Kerja berpengaruh negatif dan signifikan terhadap Komitmen Organisasi.

\section{Hipotesis 7}

Kecerdasan Emosional dan Stres Kerja secara bersama-sama memiliki total pengaruh terhadap Komitmen Organisasi sebesar $77,2 \%$ dimana angka tersebut menjelaskan bahwa secara langsung Kecerdasan Emosional dan Stres Kerja memberikan kontribusi terhadap Komitmen Organisasi sebesar 77,2\% pada frontliner Bakti BCA KCU Jambi. Hal tersebut di lengkapi dengan Hipotesis ketujuh menyatakan bahwa Kecerdasan Emosional dan Stres Kerja secara bersama-sama berpengaruh signifikan terhadap Komitmen Organisasi, hal ini terbukti berdasarkan nilai $F_{\text {hitung }} 96,233>F_{\text {tabel }}$ 0,254 atau karena nilai sig. 0,000 $<0,05$ maka Ho ditolak dan H1 diterima artinya hipotesis diterima dan signifikan. Hal ini menunjukkan bahwa secara simultan Kecerdasan Emosional dan Stres Kerja berpengaruh secara signifikan terhadap Komitmen Organisasi dan mendukung penelitian terkait dari Nikolaou, et al (jurnal:2002).

\section{Hipotesis 8}

Kepuasan Kerja secara langsung berpengaruh terhadap Komitmen Organisasi karyawan frontliner Bakti BCA KCU Jambi dengan pengaruh langsung Kepuasan Kerja terhadap Komitmen Organisasi sebesar 88\%. Hal tersebut di lengkapi dengan Hipotesis delapan menyatakan bahwa Kepuasan Kerja berpengaruh positif dan signifikan terhadap Komitmen Organisasi, hal ini terbukti berdasarkan nilai $t_{\text {hitung }}$ $20,638>t_{\text {tabel }} 1,671$ atau karena nilai sig. 0,000 < 0,05 maka Ho ditolak dan H1 diterima artinya hipotesis diterima dan signifikan. Hasil yang didapat menunjukkan bahwa Kepuasan Kerja Karyawan Frontliner Bakti PT. Bank Central Asia Tbk Cabang Jambi berpengaruh positif dan signifikan terhadap Komitmen Organisasi. Hal ini mendukung penelitian Suma (jurnal:2013) yang menyatakan Kepuasan Kerja berpengaruh positif dan signifikan terhadap Komitmen Organisasi. 


\section{Simpulan}

\section{SIMPULAN DAN SARAN}

Berdasarkan hasil analisa dan pembahasan, dapat disimpulkan bahwa:

Gambaran Kecerdasan Emosional, Stres Kerja, Kepuasan Kerja dan Komitmen Organisasi karyawan frontliner Bakti pada PT. Bank Central Asia Tbk Cabang Jambi adalah sebagai berikut:

1. Kecerdasan Emosional berada pada rentang skala kategori Tinggi (Ho ditolak dan H1 diterima).

2. Stres Kerja berada pada rentang skala kategori Tinggi (Ho ditolak dan H1 diterima).

3. Kepuasan Kerja berada pada rentang skala kategori Sedang (Ho diterima dan H1 ditolak).

4. Komitmen Organisasi berada pada rentang skala kategori Sedang (Ho diterima dan H1 ditolak).

Kecerdasan Emosional secara langsung berpengaruh positif terhadap Kepuasan Kerja dengan pengaruh langsung Kecerdasan Emosional terhadap kepuasan kerja sebesar $13,2 \%$ pengaruh tidak langsung sebesar $17 \%$ dan pengaruh total sebanyak $30,2 \%$. Hal tersebut di lengkapi dengan hipotesis kedua menyatakan bahwa Kecerdasan Emosional berpengaruh positif dan signifikan terhadap Kepuasan Kerja, hal ini terbukti berdasarkan nilai $t_{\text {hitung }} 2,019>t_{\text {tabel }} 1,671$ atau karena nilai sig. $0,048<$ 0,05 maka Ho ditolak dan H1 diterima artinya hipotesis diterima dan signifikan. Sehingga Kecerdasan Emosional berpengaruh positif dan signifikan terhadap Kepuasan Kerja.

Stres Kerja secara langsung berpengaruh negatif terhadap Kepuasan Kerja dengan pengaruh langsung Stres Kerja terhadap kepuasan kerja sebesar 25,4\% pengaruh tidak langsung sebesar $17 \%$ dan pengaruh total sebanyak 42,3\%. Hal tersebut di lengkapi dengan Hipotesis ketiga menyatakan bahwa Stres Kerja berpengaruh positif dan signifikan terhadap Kepuasan Kerja dan berdasarkan nilai $t_{\text {hitung }}-2,788<\mathrm{t}_{\text {tabel }} 1,671$ atau karena nilai sig. 0,007 $<0,05$ maka Ho ditolak dan H1 diterima artinya hipotesis diterima dan signifikan. Sehingga Stres Kerja berpengaruh negatif dan signifikan terhadap Kepuasan Kerja

Kecerdasan Emosional dan Stres Kerja secara bersama-sama memiliki total pengaruh terhadap Kepuasan Kerja sebesar 72,5\% dimana angka tersebut menjelaskan bahwa secara langsung Kecerdasan Emosional dan Stres Kerja memberikan kontribusi terhadap Kepuasan Kerja sebesar 72,5\% pada frontliner Bakti BCA KCU Jambi.

Hal tersebut di lengkapi dengan Hipotesis keempat menyatakan bahwa Kecerdasan Emosional dan Stres Kerja secara bersama-sama berpengaruh signifikan terhadap Kepuasan Kerja, hal ini terbukti berdasarkan nilai $\mathrm{F}_{\text {hitung }} 75,232>\mathrm{F}_{\text {tabel }} 0,254$ atau karena nilai sig. 0,000 $<0,05$ maka Ho ditolak dan $\mathrm{H} 1$ diterima artinya hipotesis diterima dan signifikan. Sehingga Kecerdasan Emosional dan Stres Kerja secara bersama-sama berpengaruh signifikan terhadap Kepuasan Kerja.

Kecerdasan Emosional secara langsung berpengaruh positif terhadap Komitmen Organisasi dengan pengaruh langsung Kecerdasan Emosional terhadap Komitmen Organisasi sebesar $11,9 \%$ pengaruh tidak langsung sebesar 17,6\% dan pengaruh total 
sebanyak 29,5\%. Hal tersebut di lengkapi dengan Hipotesis kelima menyatakan bahwa Kecerdasan Emosional berpengaruh positif dan signifikan terhadap Komitmen Organisasi, hal ini terbukti berdasarkan nilai $t_{\text {hitung }} 2,099>t_{\text {tabel }}$ 1,671 atau karena nilai sig. $0,040<0,05$ maka Ho ditolak dan $\mathrm{H} 1$ diterima artinya hipotesis diterima dan signifikan. Sehingga Kecerdasan Emosional berpengaruh positif dan signifikan terhadap Komitmen Organisasi.

Stres Kerja secara langsung berpengaruh negatif terhadap Komitmen Organisasi dengan pengaruh langsung Stres Kerja terhadap Komitmen Organisasi sebesar $30,1 \%$ pengaruh tidak langsung sebesar $17,6 \%$ dan pengaruh total sebanyak $47,7 \%$. Hal tersebut di lengkapi dengan Hipotesis keenam menyatakan bahwa Stres Kerja berpengaruh positif dan signifikan terhadap Komitmen Organisasi, hal ini terbukti berdasarkan nilai $t_{\text {hitung }}-3,355>t_{\text {tabel }}$ 1,671 dan karena nilai sig. 0,002 $<0,05$ maka Ho ditolak dan H1 diterima artinya hipotesis diterima dan signifikan. Sehingga Stres Kerja berpengaruh negatif dan signifikan terhadap Komitmen Organisasi

Kecerdasan Emosional dan Stres Kerja secara bersama-sama memiliki total pengaruh terhadap Komitmen Organisasi sebesar 77,2\% dimana angka tersebut menjelaskan bahwa secara langsung Kecerdasan Emosional dan Stres Kerja memberikan kontribusi terhadap Komitmen Organisasi sebesar 77,2\% pada frontliner Bakti BCA KCU Jambi. Hal tersebut di lengkapi dengan Hipotesis ketujuh menyatakan bahwa Kecerdasan Emosional dan Stres Kerja secara bersama-sama berpengaruh signifikan terhadap Komitmen Organisasi, hal ini terbukti berdasarkan nilai $F_{\text {hitung }} 96,233>F_{\text {tabel }} 0,254$ atau karena nilai sig. $0,000<0,05$ maka Ho ditolak dan $\mathrm{H} 1$ diterima artinya hipotesis diterima dan signifikan. Sehingga Kecerdasan Emosional dan Stres Kerja secara bersama-sama berpengaruh signifikan terhadap Komitmen Organisasi.

Kepuasan Kerja secara langsung berpengaruh terhadap Komitmen Organisasi karyawan frontliner Bakti BCA KCU Jambi dengan pengaruh langsung Kepuasan Kerja terhadap Komitmen Organisasi sebesar 88\%. Hal tersebut di lengkapi dengan Hipotesis delapan menyatakan bahwa Kepuasan Kerja berpengaruh positif dan signifikan terhadap Komitmen Organisasi, hal ini terbukti berdasarkan nilai thitung $20,638>t_{\text {tabel }} 1,671$ atau karena nilai sig. 0,000 < 0,05 maka Ho ditolak dan H1 diterima artinya hipotesis diterima dan signifikan. Sehingga Kepuasan Kerja berpengaruh positif dan signifikan terhadap Komitmen Organisasi.

Kecerdasan Emosional dan Stres Kerja secara langsung berpengaruh terhadap Komitmen Organisasi melalui Kepuasan Kerja dengan pengaruh langsung Kecerdasan Emosional dan Stres Kerja ke Komitmen Organisasi melalui Kepuasan Kerja sebesar 40,4\% pengaruh tidak langsung sebesar 35\% dan pengaruh total sebanyak $75,4 \%$.

\section{Saran}

Berdasarkan pembahasan hasil penelitian dan kesimpulan, maka saran yang akan diberikan sebagai berikut:

\section{Secara Praktis}

Diharapkan kedepannya manajemen BCA lebih memperhatikan untuk membekali Frontliner Bakti dengan pelatihan atau pembekalan dengan topik pengambangan diri dan pemecahan masalah sebelum penempatan di kantor cabang.

Pengaruh Kecerdasan Emosional dan Stres Kerja terhadap Kepuasan Kerja dan Dampaknya terhadap Komitmen Organisasi Frontliner Bakti PT Bank Central Asia Tbk KCU Jambi 
Karena berdasarkan hasil survey yang dilakukan responden merasa selama ini belum meyakini bisa menjadi pendengar yang baik dan memberikan solusi yang paling tepat bagi setiap kebutuhan nasabah.

Diharapkan kedepannya manajemen BCA lebih mempertimbangkan pembukaan cabang baru, menambah frontliner Bakti BCA menambah unit ATM setoran tunai, sehingga bisa mengurangi anntrian nasabah yang bertransaksi di banking hall. Karena berdasarkan hasil survey yang dilakukan frontliner Bakti BCA merasa terbebani dengan banyaknya volume dan jumlah nasabah yang bertransaksi di banking hall.

Diharapkan kedepannya manajemen BCA lebih memperhatikan pembayaran tambahan uang saku dan uang makan lembur untuk menjaga stamina frontliner Bakti BCA yang harus melakukan lembur karena pekerjaan. Manajemen BCA juga bisa lebih memperhatikan jenjang karir bagi frontliner Bakti BCA yang berprestasi agar bisa diangkat menjadi karyawan tetap. Karena berdasarkan hasil survey yang dilakukan frontliner Bakti BCA merasa kurang puas karena waktu kerja dirasakan selalu kurang untuk menyelesaikan pekerjaan dan tidak memiliki kesempatan yang yang pasti untuk bisa meneruskan karir di BCA sebagai karyawan tetap.

Diharapkan kedepannya manajemen BCA lebih memperhatikan perjanjian magang antara BCA dan frontliner Bakti BCA, untuk mengurangi turnover Bakti yang tinggi saat periode magang belum berakhir. Karena berdasarkan hasil survey yang dilakukan frontliner Bakti BCA merasa siap meninggalkan BCA kapan saja walaupun memiliki tanggung jawab dan kewajiban yang harus saya kerjakan.

Untuk meningkatkan Komitmen Organisasi, manajemen juga bisa membuat acara atau kegiatan kebersamaan yang lebih melibatkan frontliner Bakti BCA.

\section{Secara Akademis}

Penelitian ini perlu ditindaklanjuti lagi untuk melihat faktor apa saja yang dapat mempengaruhi Komitmen Organisasi. Komitmen Organisasi masih dipengaruhi oleh faktor lain, oleh karena itu perlu kajian yang lebih komprehensif guna menjawab faktor lain (epsilon) yang mempengaruhi Komitmen Organisasi.

\section{DAFTAR PUSTAKA}

Robbins, S.P. (2001). Psikologi Organisasi, (Edisi ke-8). Jakarta: Prenhallindo

Meyer, J.P, Allen N.J., and Smith C.A (1993), Commitment Organizational and Occupations: Extension and Tes of Three Component Conceptualization. Journal of Applied Psychology. 78:538-551.

Goleman (1997), Kecerdasan Emosional (terjemahan oleh : Hermaya), Jakarta: PT. Gramedia Pustaka Utama.

Goleman, Daniel (2000), Emotional Intelligence (terjemahan), Jakarta : PT. Gramedia Pustaka Utama.

Goleman,Daniel(2003), Kecerdasan Emosional, terj. T. Hermaya, Cet. XIII, Jakarta: Gramedia Pustaka Utama.

Rivai, Veithzal. \& Sagala, E.J. (2009). Manajemen Sumber Daya Manusia untuk Perusahaan. Jakarta: Rajagrafindo Persada. 
Leung, M.Y., Sham, J, \& Chan, Y.S (2007), 'Adjusting Stressors Job Demand Stress in Preventing Rustout/Burnout in Estimators', Surveying and Built Environment, Vol 18 (1), 17-26.

Rivai, Veithzal (2004), Manajemen Sumber Daya Manusia Untuk Perusahaan, Jakarta : PT. Raja Grafindo Persada.

Kreitner, Robert (2005), Organizational Behavior, Jakarta : Salemba Empat.

Luthans (2002), Performance and Motivation, New York: Prentice Hall.

Mojgan Emdady dan Nasrin Bagheri (2013), The relation between emotional intelligence and job satisfaction, European Journal of Experimental Biology, 3(1):554-558

Simin Bemana et al (2013), The Relationship among Job Stress and Job Satisfaction in Municipality Personnel in Iran, World Applied Sciences Journal 22 (2): 233238, ISSN 1818-4952

Azman Ismail et al (2010), Occupational Stress Features, Emotional Intelligence And Job Satisfaction: An Empirical Studu In Private Institutions Of Higher Learning, Scientific e-journal of Management Science, ISSN 1856-1810

Oznur Tulunay Ates (2015), The Relationship between the Emotional Intelligence, Motivation and Organizational Commitment of Primary School Teachers, Middle Eastern \& African Journal of Educational Research, Issue 17

Ameneh Aghabozorgi (2014), Impact Of Emotional Intelligence On Organizational Commitment Of Nurses In The Public Hospitals Of Sanandaj, Indian Journal of Fundamental and Applied Life Sciences ISSN: 2231- 6345

Christien A. Karambut dan Eka Afnan T, Noormijati (2012), Analisis Pengaruh Kecerdasan Emosional, Stres Kerja dan Kepuasan Kerja terhadap Komitmen Organisasional (Studi pada Perawat Unit Rawat Inap RS Panti Waluya Malang, Jurnal Aplikasi Manajemen, Volume 10, Nomor 3

Ioannis Nikolaou dan Ioannis Tsaousis (2002), Emotional Intelligence in the workplace: exploring its effect on occupational stress and organizational commitment, The International Journal of Organizational Analysis, Vol 10

Saimir Suma (2013), Job Satisfaction And Organizational Commitment: The Case Of Shkodra Municipality, European Scientific Journal edition vol.9, No.17 ISSN: $1857-7881$

Pengaruh Kecerdasan Emosional dan Stres Kerja terhadap Kepuasan Kerja dan Dampaknya terhadap Komitmen Organisasi Frontliner Bakti PT Bank Central Asia Tbk KCU Jambi 